\title{
HUMOVA STOPA V KANTOVĚ FILOSOFII
}

\section{Milan Sobotka}

\author{
Se vzpomínkou na Milana Machovce
}

\section{Úvod}

Práce o Kantově teorii „představy“ se dnes zabývají rozvinutím významu „představy“ u Reinholda, prŕíp. dalších Kantových následovníků. ${ }^{1}$ Přitom ustupuje do pozadí, že nikoli Reinhold a další Kantovi následovníci, ale již Kant dovršuje cestu novověké filosofie k jistotě jejího východiska tím, že pojal představu jako základní fenomén filosofie bez ohledu na to, zda je, či není výsledkem vlivu vnější skutečnosti. Kant považuje rozdíl vědomí předmětu a vědomí sebe sama za rozdíl uvnitř vědomí (je to rozdíl „vnějšího“ a „vnitřního smyslu“). ${ }^{2} \mathrm{~V}$ tom se setkává s Humem, který analyzuje percepci jako základní fenomén mysli, bez ohledu na to, zda je, či není výsledkem vlivu vnějšího předmětu, tvořivé síly mysli nebo vlivem původce všeho, jak sám rríká. ${ }^{3}$ Byl to David Hume, který v kartesiánské tradici jistoty subjektu myslícího sama sebe vidí v představě mysli východisko filosofie a který, na rozdíl od Descarta či Locka, ji chápe nikoli jako prezentaci vnějšího předmětu, nýbrž jako autonomní entitu, která je jedinou původní a nepochybnou daností, z níž může filosofie vycházet.

Učiníme-li východiskem filosofie subjekt, jak to činí novověká filosofie, položíme tím důraz na to, co je dáno poznávajícímu subjektu, na představy. Protože představy jsou nám dány v souvislé zkušenosti, je nutné zkoumat i celou zkušenost jako průběžnou jistotu. To učinil již Locke, který považuje pojmy substance a kauzality za jednotící prvky

1 Srv. M. Bondeli - A. Lazzari (vyd.), Philosophie ohne Beynamen, Basel 2004, str. $21 \mathrm{n}$.

2 I. Kant, Kritika čistého rozumu, přel. J. Loužil - J. Chotaš - I. Chvatík, Praha 2001, A 22, B37, str. 55.

3 D. Hume, Pojednání o lidské přirozenosti, přel. H. Janoušek, Praha 2015, str. 155 . 
naší zkušenosti. ${ }^{4}$ Substance a kauzalita nejsou smyslové dojmy, jsou to výtvory rozvažování, které by ovšem nevznikly, kdyby se nám počitky nepodávaly ve stálé souslednosti a následnosti, na niž si zvykneme. Pojmy substance a kauzality spíše jen ,sankcionují “5 tento obvyklý průběh smyslových dojmů. Locke je ovšem ještě přesvědčen, že naše smyslové dojmy jsou vyvolávány vnějšími předměty.

Na Locka navazuje Hume, který rovněž vychází ze „souvislosti a stálosti“" impresí, jež jsou stavebními kameny zkušenosti, přičemž podobnost, soumeznost (contiguity) a kauzalita jsou tou ,jemnou silou“ ", která sjednocuje jednoduché ideje v ideje složité. Naši zkušenost dále sjednocují ideje substance a modů jako souborů jednotlivých idejí, které jsou sjednoceny obrazností. Rozbor vrcholí výkladem belief, „víry“, která provází naše imprese, a osobní identity. Nejdůležitější stránkou tohoto výkladu je teze, že belief, jíž přikládáme impresím a idejím, sjednoceným pamětí a zvykem, význam vnějšího světa, není nějaký význam navíc, že jeho povahu nelze vůbec hledat v tomto směru, nýbrž že je to pocit, feeling či sentiment, ${ }^{8}$ který nutně provází imprese.

Svou koncepcí autonomie percepcí, jimž možná odpovídá, ale možná neodpovídá něco za jejich hranicemi, aniž by to na autonomním statusu percepcí cokoli měnilo, způsobil Hume v německé filosofii revoluci v pojetí noetického subjektu. Až do té doby se pokládalo za samozřejmé, že naše smyslové představy jsou ,ideové obrazy“, tj. že se vztahují k vnější realitě. „Ideové obrazy“, „obrazové ideje“,9 jimiž nás obdařuje náš „duševní orgán“"10 $\mathrm{z}$ podnětu vnějšího předmětu, byla charakteristikou smyslových představ ve Filosofických aforismech Ernsta Platnera, které Kant použival jako kompendia ke svým přednáškám.

Platner však v době Kantovy Kritiky čistého rozumu nebyl představitelem převládajícího pojetí. Tím byl spíše, jak můžeme soudit podle názoru muže, s nímž vede rozhovor Friedrich H. Jacobi ve spise Idealismus a realismus (1787), Johann $\mathrm{N}$. Tetens, autor práce $O$ obecné

4 R. Brandt, John Locke, in: O. Höffe (vyd.), Klassiker der Philosophie, München 2008.

5 Tamt., str. 364.

6 D. Hume, Pojednání o lidské přirozenosti, str. 271.

7 Tamt., str. 76.

8 D. Hume, An Enquiry concerning Human Understanding, vyd. A. Flew, La Salle (I1l.) 1994, str. 91.

9 E. Platner, Philosophische Aphorismen, Leipzig 1784, str. 42.

10 Tamt. 
spekulativní filosofii a Filosofických pokusůo o lidské přirozenosti a jejím vývoji (1776-1777). Na Tetense, který zná Huma, poukazuje již termín „počitek“, Empfindung, na jehož prríčinu ve vnějším světě usuzujeme. Tetens hned na začátku své práce o spekulativní filosofii uvádí Humovu metaforu o mysli jako „divadelní scéně“ ${ }^{11}$ ovšem chápe ji dualisticky. Zatímco Hume chce prríměrem vyjádřit, že mysl je cosi jako projekční plátno, na němž se objevují percepce, mluví Tetens o ,řadě idejí, která se nám jeví jako scéna $\mathrm{v}$ nás, nikoli jako řada věcí mimo nás“. Proto rozlišuje „zkoumání představ“ a „filosofii o objektech“. ${ }^{12}$

Ale na tom lze právě určit význam Jacobiho pojetí, které bychom mohli označit za „revoluční“, kdyby nebyl Jacobiho předešel Kant svou Kritikou čistého rozumu. Kant zde začíná tím, že jsou nám „dány“ prostřednictvím ,smyslovosti předměty“13 a že „neurčený předmět empirického názoru se nazývá jev“. ${ }^{14}$ Dnešní interpret mluví o „takzvaných předmětech“, na něž je zaměřeno myšlení v našem poznání. ${ }^{15}$ Ale od tohoto humovského, jak se domníváme, začátku, který je pak důrazně potvrzen ve 4. paralogismu prvního vydání Kritiky, kde Kant mluví o tom, že vnější předměty, jichž jsme si vědomi, nejsou věci o sobě, nýbrž jen „představy“, ,jichž si můžeme být bezprostředně vědomi tak jako každé jiné představy“", ${ }^{16}$ ale jichž jsme si vědomi jako vnějších věcí, pokračuje Kant výkladem „transcendentálního předmětu“ ve smyslu nám neznámého základu našich jevů „vnějšího smyslu“. Kant tedy přechází od humovského začátku ke zkoumání vnějšího základu jevů naší mysli. Výsledkem tohoto zkoumání je teze, jíž si všímá Jacobi, že „tytéž předměty musíme být s to, ne-li rovnou poznávat, tedy alespoň myslet jako věci o sobě “. ${ }^{17}$ To se promítá do Úvodu k druhému vydání Kritiky, kde Kant mluví o ,předmětech, které podněcují (rühren) naše smysly a samy ... vyvolávají představy...". ${ }^{18}$ Tím je původní humovské východisko

11 D. Hume, Pojednání o lidské přirozenosti, str. 330.

12 J. N. Tetens, Philosophische Versuche über die menschliche Natur und ihre Entwicklung, Berlin 1913, str. 4 n.

13 I. Kant, Kritika čistého rozumu, A 19, B 33, str. 53.

14 Tamt., A 20, B 34, str. 54.

15 R. Brandt, Transzendentale Ästhetik, $\oint \oint 1-3$, in: G. Mohr - M. Willaschek (vyd.), I. Kant, Kritik der reinen Vernunft (Klassiker Auslegen, 17/18), Berlin 1998, str. 83.

16 I. Kant, Kritika čistého rozumu, A 378, str. 548.

17 Tamt., B XXVI, str. 24.

18 Tamt., B 1, str. 33. 
zastřeno. Nebyl to Kant, ale Jacobi, který mohl Němce seznámit s podstatou Humova myšlení.

Jacobi vychází z vysvětlení našeho vědomí vnějšího světa jako charakteristiky ,jevu“. Naše představy se nám jeví jako vnější svět. To je „slepá jistota“ podmíněná naší přirozeností. ${ }^{19}$ „Rozhovor“, jak zní podtitul Jacobiho knihy, začíná zmínkou o tom, že Jacobi je stíhán výtkou $\mathrm{z}$ „,nepodmíněné slepé víry“ ${ }^{20}$ Rozhovor se záhy stočí k Humovi, protože Jacobi svému návštěvníku vysvětluje, že původcem slova „víra“ (belief) je Hume. Jacobi toho využívá k polemice se dvěma články v Allgemeine Literatur-Zeitung, v jejichž duchu návštěvník prohlašuje, že ,ppocit’uje“ (empfindet), že s ním Jacobi sedí a mluví.

Jacobi nechává návštěvníka reprodukovat myšlenky z uvedeného článku: „Nevěřím, že mám tělo a že mimo nás a jiné myslící bytosti jsou jiná tělesa, nýbrž pocit'ujeme sebe samotné, pocit'ujeme své tělo a jiná tělesa mimo nás a usuzujeme na myslící bytosti mimo nás. " ${ }^{21} \mathrm{Na} J a c o b i-$ ho otázku po povaze onoho pocit’ování odpovídá návštěvník, že Jacobi není předmětem jeho pocit’ování, ale vnější prř́činou jeho pocitování. ${ }^{22}$ „Vy jste si vědom počitku a v tomto počitku jiného počitku, jímž pocit'ujete, že tento počitek je př́činou onoho (prvního - M. S.) počitku; a to dohromady vytvárí představu, která obsahuje něco, co nazýváte předmětem? Odkud víte, že počitek příčiny, počitek skutečného předmětu, je mimo váš počitek?"23 Skutečně: proč nám nepostačuje počitek věci jako takový, proč za ním předpokládáme příčinu, což Jacobi vyjadřuje myšlenkou, že v počitku jsme si vědomi jiného počitku? Jacobi se odvolává na Huma, sice nikoli na jeho Pojednání, ale na jeho Zkoumání, $\mathrm{v}$ jehož 5. oddíle je sumarizována nauka o belief z Pojednání. ${ }^{24}$ Hume přitom nevylučuje, že naše percepce jsou vzbuzovány vnějším zdrojem, ale těžiště jeho výkladu spočívá v teorii, že předmětný smysl percepcí je vysvětlitelný čistě imanentně. Mysl přikládá silným a živým percepcím - impresím (a v některých případech i idejím $)^{25}$ význam vnějších

19 F. H. Jacobi, David Hume über den Glauben, oder Idealismus und Realismus. Ein Gespräch, in: týž, Werke, II, Leipzig 1815, str. 143.

20 Tamt., str. 138.

21 Tamt., str. 148.

22 Tamt.

23 Tamt., str. 142.

24 D. Hume, Zkoumání o lidském rozumu, přel. J. Moural, Praha 1996, str. 80.

25 D. Hume, Pojednání o lidské přirozenosti, str. 193, 364. D. Hume, Zkoumání o lidském rozumu, str. 85. 
předmětů, ačkoli existenci vnějších předmětů není schopna dokázat. To je ona filosofická revoluce, s níž nás Jacobi seznamuje.

Jacobi nyní shrnuje nauku o belief, protože v ní vidí klíč k Humově i Kantově filosofii a protichůdné stanovisko ke své vlastní filosofii. Jacobi se přitom opírá o předpoklad, že „existuje vnímání v nejpřísnějším smyslu, v němž se vyjevuje, zjevuje (offenbaren) vnější skutečnost“", zatímco podle Kanta ,představy znázorňují jen sebe samy“. ${ }^{26}$ Podle Kanta svými smysly člověk dostává ,jen představy, které se ovšem mohou vztahovat na předměty o sobě existující a nezávislé na těchto představách, které však neobsahují nic z toho, co náleží předmětům existujícím nezávisle na představách“. ${ }^{27}$ Jacobiho vlastní stanovisko je tomu protikladné, ale Jacobi dává najevo, že jde o filosofický objev. Je to situace obdobná jeho výkladu Spinozovy filosofie, kde sice Jacobi vystupuje proti Spinozovi, ale zároveň objevuje jeho filosofický význam.

S pojmem belief je spojen status našich představ jako jevu. Jacobi při jeho výkladu navazuje na obtíž definovat přesně belief:

„Tato rozmanitost výroků, která se může zdát velmi nefilosofickou, má jedině ten účel, aby byl označen onen akt duše, v němž reálno nebo to, co je za ně považováno, nabývá více př́itomnosti, více váhy pro rozvažování a větší vliv na vášně a obraznost než to, co je vymyšleno. Je zbytečné prŕit se o slova, jsme-li ve věci zajedno. Obraznost má vládu nad svými představami; může je mísit všemi možnými způsoby a měnit; může vytvářet vymyšlené předměty se všemi okolnostmi místa a času; může nám je stavět před oči s úplným vzezřením pravdy... Protože však přesto obrazotvornost s touto mohutností to nikdy nemůže dovést tak daleko, aby způsobila víru, je jasné, že víra nezáleží ve zvláštní přirozenosti nebo řádu představ, nýbrž ve způsobu jejich vnímání (Wahrnehmung) a v tom, jak jsou pocit'ovány. Přiznávám, že je nemožné tento druh vnímání dokonale objasnit..., ale pravé vlastní slovo pro to je víra, výraz, jemuž každý v obyčejném životě rozumí. A filosofie nemůže dokázat víc, nýbrž musí zůstat u toho, že víra je něco duší pocit'ovaného, co odlišuje přitakání skutečnu a jeho představu od výmyslů obrazotvornosti. Tím nabývají

26 F. H. Jacobi, Vorrede, zugleich Einleitung in des Verfassers sämmtliche philosophische Schriften, in: týž, Werke, II, str. 36.

27 Tamt., str. 35. 
ony představy váhy a vlivu, nabývají větší vážnosti, pronikají duši a stávají se vládnoucím principem našich jednání.“28

Všimněme si důsledně imanentistického rázu tohoto výkladu představ, jimž přičítáme význam skutečnosti - mít více váhy a vlivu, zajímat nás více než pouhé fikce, stát se vedoucím principem našich jednání. Jacobi zde vystihuje ducha Humova skepticismu.

Prvním krokem je teze, že to, čeho jsme si vědomi, nejsou vnější předměty, nýbrž jevy, že naše poznání je jevení v modu, ,jako by“ jeho předměty byly vnější skutečností. Druhým krokem je zdůraznění, že vědomí existence vnějších předmětů nezáleží ve zvláštní ideji ${ }^{29}$ která by přistupovala $\mathrm{k}$ impresi předmětu a vyvolávala náš souhlas $\mathrm{s}$ jejím předmětným pojetím. Belief záleží pouze $\mathrm{v}$ pocitu, jímž mysl přitakává (assent $)^{30}$ svým impresím. Hume přitom v Pojednáni ${ }^{31}$ i ve Zkoumáni ${ }^{32}$ ř́ká, že slova „sentiment“ či „feeling“ nevyjadřují přesně povahu „víry“, ale že není schopen podat její přesnější popis. Jacobi parafrázuje: „V čem tedy spočívá rozdíl mezi představovat si (sich einbilden) a vírou? Naprosto ne ve zvláštní představě, která by byla spojena s představou toho,

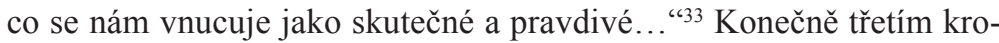
kem je neodvoditelnost „reálna nebo toho, co je za ně považováno“. 34

$\mathrm{Na}$ tom je založen pojem jevu. Z toho, že existence vnějších věcí je nanejvýš domněnkou, vyplývá, že věci se nám ,jeví jako (existující) mimo nás"“:35

„Že by však tyto věci přesto nebyly pouhými jevy v nás, nebyly pouhými určeními našeho vlastního já, a v důsledku toho neexistovaly jako [pouhé - M. S.] představy něčeho mimo nás, nýbrž že by se - jako představy v nás - vztahovaly na skutečně vnější, o sobě existující jsoucna a pocházely od nich: proti tomu lze vznést nejen pochybnosti,

28 F. H. Jacobi, David Hume, oder Idealismus und Realismus, str. $162 \mathrm{n}$.

29 Tamt., str. 159.

30 D. Hume, Pojednání o lidské přirozenosti, str. 376.

31 Tamt., str. 353.

32 D. Hume, Zkoumání o lidském rozumu, str. 81.

33 F. H. Jacobi, David Hume, oder Idealismus und Realismus, str. 152.

34 Tamt., str. 159.

35 Tamt., str. 143. 
ale bylo také mnohokrát dokázáno, že tyto pochybnosti nemohou být vyvráceny rozumovými důvody $\mathrm{v}$ př́ísném slova smyslu. “36

Jenže s tím se rozchází Kantova teze z vydání B Kritiky čistého rozu$m u$, podle níž by bylo nesmyslné, aby jev existoval bez něčeho, co se jeví. ${ }^{37}$ Jacobi považuje tuto větu a celou nauku o věci o sobě za vykloubení Kritiky čistého rozumu z transcendentálního idealismu, jak Kantovo stanovisko - v souhlasu s Kantem - nazývá. S tímto předpokladem by celý transcendentální idealismus zanikl, a proto musí jeho vyznavač nechat onen předpoklad padnout a nesmí ani chtít považovat za pravděpodobné, že existují věci, které bychom byli s to nějakým způsobem vnímat. ${ }^{38}$ Pokud to chce učinit pravděpodobným, pokud tomu chce věřit i jen vzdáleně, musí vystoupit $\mathrm{z}$ transcendentálního idealismu a upadnout do skutečně nevyslovitelných rozporů. ${ }^{39}$ Transcendentální idealismus je stanovisko „transcendentální nevědomosti“ ${ }^{40}$ ř́íá Jacobi v príloze O transcendentálním idealismu.

Jacobi uznává za Kantovo autentické stanovisko verzi z vydání A. V konfrontaci se svým stanoviskem dokazuje, že Kant je subjektivista - „,naše celé poznání není než vědomí spojených určení našeho vlastního já“ ${ }^{41}$ Látku našich představ tvoří jen ,,počitek, modifikace našeho já““ ${ }^{42}$ Rozvažování je pouhé spojování smyslových představ, proto mu nenáleží hodnota druhého zdroje našeho poznání. V souvislosti s tím Jacobi kritizuje Kantovo odvození kategorií z logické funkce soudů. Ale i kdyby uznal funkce soudů, které se objektivizují v kategoriích, za legitimní zdroj poznání, neměnilo by to nic na jeho stanovisku, které měří Kanta tím, zda umožňuje př́istup k předmětům o sobě. Protože rozvažování je jen prodloužením smyslovosti, je smyslovost - spolu s obrazotvorností $^{43}$ - podle Kanta základem všeho našeho poznání. Všechno naše poznání je podmíněno smyslovostí a zaměřeno na smyslovost „naprosto

\footnotetext{
36 Tamt., str. 143.

37 F. H. Jacobi, Vorrede, zugleich Einleitung, str. 35. Ke Kantově tezi viz Kritika čistého rozumu, B XXVI, str. 24.

38 F. H. Jacobi, David Hume, oder Idealismus und Realismus, str. 309.

39 Tamt., str. 310.

40 Tamt.

41 Tamt., str. 406.

42 F. H. Jacobi, Vorrede, zugleich Einleitung, str. 39.

43 Tamt., str. 32.
} 
pouze jako prostředek “ ${ }^{44}$ ř́ká Jacobi odvolávaje se na transcendentální estetiku. $^{45}$

Jacobi uznává, že Kant zná i „vzmach“ filosofie, která překračuje smyslovost směrem $\mathrm{k}$ idejím ${ }^{46}$ ale zároveň Kantovi upírá možnost poznat něco z inteligibilního světa. Kant sice tomuto poznání zajistil „prázdné místo“ ve své spekulativní filosofii, ale toto prázdné místo musí zůstat nevyplněno, protože u Kanta není jasné, proč může praktický rozum dojít dále než rozum spekulativní. Jacobi se přitom odvolává na $\mathrm{No}$ vou kritiku rozumu (Neue Kritik der Vernunft) Jakoba F. Friese. ${ }^{47} \mathrm{Z}$ toho vyplývá, že filosofie jako „věda překračující oblast smyslovosti““48 není u Kanta možná.

Protože Jacobi neuznává roli kategorií v našem poznání, jeví se mu smysl „transcendentálního idealismu“ jen v tom, že poznáváme jevy a nikoli vnější věci, nicméně že je poznáváme s vědomím, že jsou to vnější věci. Je to Kantův pojem „skeptického idealismu“ ze 4. paralogismu: „Skeptický idealismus je tedy jediné útočiště, které nám zbývá, totiž chopit se ideality všech jevů, kterou jsme v transcendentální estetice prokázali..." " Skeptický idealismus Kant ztotožňuje s „transcendentálním idealismem“: „Pro tento transcendentální idealismus jsme se vyslovili hned na začátku“ ${ }^{50} \mathrm{tj}$. $\mathrm{v}$ transcendentální estetice:

„Transcendentálním idealismem všech jevů rozumím nauku, podle níž je [jevy - M. S.] všechny považujeme za pouhé představy, a nikoli za věci samy o sobě, a podle níž jsou čas a prostor jen smyslovými formami našeho názoru, a nikoli pro sebe danými určeními nebo podmínkami objektů jako věcí samých o sobě. “51

Že stanoviskem transcendentálního idealismu, které Kant staví proti „transcendentálnímu realismu“, je Humova filosofie, Kant neříká. Hume je mu prŕkladným představitelem skepticismu. ${ }^{52}$ Všechny odkazy

\footnotetext{
44 Tamt.

45 I. Kant, Kritika čistého rozumu, A 29, str. 53.

46 F. H. Jacobi, Vorrede, zugleich Einleitung, str. 30.

47 Tamt., str. 24.

48 Tamt., str. 30.

49 I. Kant, Kritika čistého rozumu, A 378, str. 553.

50 Tamt., A 370, str. 548.

51 Tamt., A 369, str. 547-548.

52 Tamt., B 19, str. 45.
} 
na Huma (jde ještě o poukaz u syntetických vět $a$ priori $^{53}$ a na pojem kauzality v Prolegomenech) ${ }^{54}$ se vztahují k problému transcendentalismu, k němuž Hume ukázal Kantovi cestu, ač sám mu byl vzdálen. Hume ukázal, že zdánlivě zcela objektivní vztah může být založen v subjektu.

Kant blíže rozebírá transcendentální idealismus takto: Transcendentální idealismus je empirický realismus - přiznává hmotě skutečnost. Uznává hmotu v jejích podobách a proměnách - ovšem pouze jako jev, tj. jako představy, jichž jsme si bezprostředně vědomi. Může sice ,připustit, že př́čcinou našich vnějších názorů je něco, co může být mimo nás, ale není to předmět, jaký rozumíme pod představou hmoty a tělesných věcí' ${ }^{55}$ Transcendentální předmět jako skutečný základ jevů je nám neznámý, nelze o něm nic říci, mluvit můžeme pouze o „empirickém předmětu, který se nazývá vnějším, pokud si ho představujeme v prostoru, a vnitřním, pokud si ho představujeme pouze v časovém vztahu, prostor a čas se však nacházejí pouze v nás“ ${ }^{56}$ Protože výraz „mimo nás“ je dvojznačný - označuje věc, která existuje odděleně od nás, stejně jako věc, která patří $\mathrm{k}$ našemu vnějšímu názoru -, bude Kant $\mathrm{v}$ případě empirického realismu mluvit o věcech, které se nacházejí v prostoru, nikoli však mimo prostor jako formu našeho vnímání.

Pro empirický realismus v Kantově smyslu platí, že 1) vjem je představou skutečnosti, 2) že tato skutečnost je představována v prostoru a 3) že jako skutečné platí jen to, co je v něm představováno. Oproti Humovi využívá Kant té přednosti němčiny, že slovo ,představovat“ (vorstellen) a ,představa““ (Vorstellung - Humovo perception) jsou ze stejného slovního kořene. „Toto vnímání představuje tedy (abychom pro tentokrát zůstali jen u vnějších názorů) něco skutečného v prostoru. " ${ }^{\text {"57 }}$

Kant tedy - stejně jako Jacobi - považuje transcendentální idealismus za filosofii jevení, přičemž čas a prostor jsou formami nazírání, v němž se jevy prezentují. Ale Kant odtud právě v té části Kritiky, která následuje po vysvětlení transcendentálního idealismu, přechází k výkladu předmětného smyslu našich představ a k analýzám transcendentálního předmětu jako onoho „něčeho“, co musí stát za empirickým předmětem, tedy k „věci o sobě“. Kant nepřechází k teorii „věci o sobě“, která „existuje

53 Tamt., B 128, str. 106.

54 I. Kant, Prolegomena ke každé přišti metafyzice, přel. J. Kohout - J. Navrátil, Praha 1972, str. 44.

55 I. Kant, Kritika čistého rozumu, A 372, str. 549.

56 Tamt., A 373, str. 549.

57 Tamt., A 374, str. 550. 
odděleně od nás“" ${ }^{58}$ svévolně, jak mu to vytýká Jacobi, když říká, že Kant odvozuje ,věc o sobě“ z pouhého pojmenování ${ }^{59}$ (jevy předpokládají něco, co se jeví). Jacobi přitom poukazuje na předmluvu k 2 . vydání Kritiky čistého rozumu. ${ }^{60}$

\section{Transcendentální dedukce, transcendentální apercepce}

Abychom mohli vysvětlit Kantovu teorii zpředmětňování našich představ, musíme se seznámit s teorií transcendentální dedukce kategorií a transcendentální apercepce, tj. sebevědomí. V následujícím výkladu se omezíme na význam sebevědomí ve smyslu transcendentální apercepce, i když jsme si vědomi toho, že Kantova teorie sebevědomí obsahuje další aspekty vědomí sebe sama (vztah smyslové a intelektuální stránky sebevědomí), které byly v pokantovské filosofii různým způsobem vykládány, rozvíjeny i zpochybňovány. ${ }^{61}$ Transcendentální dedukce kategorií má podat důkaz kategorií jako osnovy empirické složky naší zkušenosti - tato osnova do ní vnáší nutnost - způsobem, který je zvlášt’ přesvědčivý: dosvědčením jejich platnosti je průběh vědomí, v jehož každém okamžiku jsem si schopen uvědomit: ,já jsem.“ Při tomto výkladu necháváme stranou otázku předlogické konstituce já před vztahem k vnější zkušenosti ${ }^{62}$ a omezujeme se na souvislost vnější zkušenosti a vědomí sebe sama, kterou Kant nejlépe vyjádřil ve „Vyvrácení idealismu“: „,.. dokázat, že naše vnitřní, pro Descarta nepochybná zkušenost, je možná jen za předpokladu vnějš̌́ zkušenosti. “63 Výklad ,já jsem“ a personální identity vědomí je subjektivní stránkou transcendentálního dějství, jehož objektivní stránkou je transcendentální dedukce kategorií. Průběh vědomí sám by byl neustále proměnlivý a ,v ... proudu vnitřních jevư “ by nemohl poskytnout žádné „stálé a trvalé já“, ${ }^{64}$ kdyby jeho empirická složka, obrácená zevně, nebyla řízena neúchylnou zákonitostí,

58 Tamt., A 373, str. 550.

59 F. H. Jacobi, Vorrede, zugleich Einleitung, str. 36.

60 I. Kant, Kritika čistého rozumu, B XXVI, str. 24.

61 Srv. K. Gloy, Bewusstseinstheorien, Freiburg i. Br. - München 1998, str. $161 \mathrm{n}$.

62 Srv. M. Bondeli, Apperzeption und Erfahrung: Kants transzendentale Deduktion im Spannungsfeld der frühen Rezeption und Kritik, Basel 2006, str. 46.

63 I. Kant, Kritika čistého rozumu, B 275, str. 182.

64 Tamt., A 107, str. 524. 
s níž vědomí sjednocuje smyslový názor. Vědomí identické aktivity při zvýznamňování a sjednocování smyslové rozmanitosti v nutnou a předmětnou zkušenost je základem personální identity vědomí. Sjednocování smyslového názoru ve zkušenost, která je zkušeností o předmětech, jež jsou substancemi a jejichž časová posloupnost je podmíněna kategorií kauzality, probíhá ve třech stupních, které Kant probírá ve vydání A následovně: prvním stupněm je transcendentální aprehenze, schopnost „projít a shrnout představu“ ${ }^{65}$ Shrnutí jednotlivé představy v představu jako jednotku, k níž mohou být připojeny další jednotky, aby mohla vzniknout „smyslová rozmanitost“, je prvním krokem syntézy našich představ, které by bez syntéz tvořily jen zmatené pole dojmů. Na rozdíl od Huma je spojení předchozího s následným v naší mysli podmíněno nejen asociativně, nýbrž především jednotou záměru, jehož cílem je uskutečnit zkušenostní poznání. Proto jsou stupně smyslového sjednocování zkušenosti podřízeny kategoriím.

Druhou syntézou je „reprodukce v obraznosti“, schopnost reprodukovat minulý průběh představ. $\mathrm{V}$ obou případech jde o syntézy, které se odehrávají ve smyslovosti a které by připustil i anglický empirismus, s nímž se Kant konfrontuje. Je přece základní myšlenkou Lockova a Humova empirismu, že myšlenka nutného spojení mezi předchozím jevem mysli a jevem následujícím je produktem zvyku, že vždycky určité události následují po sobě, tak jako je pojem substanciality výrazem zvyku, že se určité jevy vyskytují „,vedle sebe“. Ale Kant hned na začátku výkladu „syntézy reprodukce“ poznamenává, že podmínkou toho, aby představy, „které po sobě často následovaly nebo se doprovázely“, vedly ke zvyku a očekávání téhož průběhu v budoucnosti, je „,neměnnost pravidla tohoto průběhu“. ${ }^{66}$ Tím poukazuje na transcendentální dedukci.

Transcendentální dedukce čistých rozvažovacích pojmů je dokazována prostřednictvím transcendentální apercepce, tedy teorie, že pouze nutný průběh obsahů vědomí zaručuje stálost a trvalost já. Výklad transcendentální dedukce se prolíná s výkladem transcendentální apercepce, která však transcendentální dedukci přesahuje, ${ }^{67}$ protože posledním slovem v jejich vztahu je personální identita. Nedostatečně stálé a trvalé já, které Kant přičítá anglickému empirismu, se nazývá „,vnitřní smysl nebo

65 Tamt., A 99, str. 521.

66 Tamt., A 100, str. 521.

67 H. Hoppe, Die transzendentale Deduktion in der ersten Auflage, in: G. Mohr M. Willaschek (vyd.), I. Kant, Kritik der reinen Vernunft, str. 165 n. 
empirická apercepce“. ${ }^{68}$ Tím Kant dává najevo svou kritiku anglického empirismu, který vyvozuje vědomí sebe sama ze zvyku na pravidelný průběh asociativně spojených smyslových dojmů. ${ }^{69}$ Vztah empirické zkušenosti a personálně identického já u Kanta se dnes formuluje jako „intencionální' ${ }^{\prime \prime 0}$ oblouk (ve směru k poznání zkušenostních předmětů), v němž se uskutečňuje transcendentální apercepce.

Zvyk na empirický průběh zkušenosti nemůže zaručit nepodmíněnou jednotu vědomí, nýbrž jen rozptýlené, „mnohobarevné já“‘ ${ }^{71}$ Personální identita je možná jen tehdy, je-li tu podmínka, která předchází veškerou zkušenost a která ji - jako zkušenost nutnou - činí možnou. Tuto podmínku splňuje já tím, že smyslový názor „myslí“, tj. že na něj aplikuje své logické funkce, které se tím stávají kategoriemi, jež zvýznamňují a sjednocují empirické danosti názoru v empirickou zkušenost. Kategorie jsou pojmy předmětu vůbec, jejichž pomocí je názor předmětu určen vzhledem k některé z „logických funkcí souzení““.72 „Já myslím“ znamená: 1) zvýznamňuji veškerou empirickou zkušenost vzhledem k logickým funkcím myšlení; 2) protože zákonitou souvislost představ vytvárím prostřednictvím logických funkcí svého ,já“", mohu si být „,vědom identity funkce, pomocí níž jednota apercepce spojuje rozmanitost synteticky v jeden poznatek“. V následující větě používá Kant příslovce „zároveň“ (zugleich) o vztahu syntézy všech jevů zkušenosti k „,vědomí identity sebe sama“"

„Původní a nutné vědomí identity sebe sama je tedy zároveň vědomím právě tak nutné jednoty syntézy všech jevů podle pojmů [tj. podle kategorií, objektivizovaných logických funkcí - M. S.], tj. podle pravidel." ${ }^{\text {"73 }}$

Nyní Kant přistupuje $\mathrm{k}$ dalšímu důležitému bodu své transcendentální teorie, podle něhož je ,předmět“, jehož jsme si při empirické představě vědomi, významem, který k ní přistupuje, jestliže jde o nutnou zkušenost. Kant podle Humova vzoru zastává názor, že přesvědčení o realitě či existenci věcí mimo nás není důsledkem další představy, nýbrž že jde o to,

68 I. Kant, Kritika čistého rozumu, A 107, str. 525.

69 D. Hume, Pojednání o lidské přirozenosti, str. 337.

70 H. Hoppe, Die transzendentale Deduktion, str. 172.

71 I. Kant, Kritika čistého rozumu, B 134, str. 110.

72 Tamt., A 294, B 351, str. 229, B 128, str. 107.

73 Tamt., A 108, str. 525 (překlad upraven). 
že naše empirická zkušenost má předmětný smysl. Výklad, jehož historický význam pro německý idealismus nelze přecenit, ${ }^{74}$ začíná v A 103 explikací toho, co znamená pojem (předmětu). Kant nazývá pojmem souhrnnou představu předmětu, která vznikne přidáváním dalších představ a která je syntetizována kategoriemi. Kant přitom poukazuje na identitu vědomí, ,jedno vědomí“, které spojuje rozmanitost „postupně nazíranou a pak také reprodukovanou... v jednu představu“" ${ }^{75}$ rozumí se představu věci. Jedno vědomí (výraz se v následující větě opakuje) znamená, že je to identické ,já myslím“, které shrnuje více dřívějších vjemů, jež našemu vědomí poskytly části nebo dílčí aspekty pojmu nějaké věci. Kant přitom poznamenává, že by bylo chybné považovat ,jevy“ za předměty - jevy „samy o sobě... nesmějí být pokládány za předměty (existující mimo představivost)““ ${ }^{76}$ Tím je připraven úderný závěr: „Co se tedy rozumí tím, když se mluví o předmětu, který odpovídá poznání, a je proto také od něj odlišný?" Podle Kanta lze snadno pochopit, že tento předmět není žádná vnější entita, nýbrž že to je význam, který k našemu ,pojmu“ přistupuje, „protože kromě našeho poznání nemáme přece nic, co bychom proti tomuto poznání mohli klást jako něco, co mu odpovídá““.77

Blíže Kant tento význam ,předmětu“ osvětluje větou, kterou o 16 let později bude parafrázovat Johann G. Fichte ve svém Druhém úvodu do vědosloví:

„... př̀edmět je považován za něco, co nedovoluje, aby naše poznatky byly nahodilé nebo libovolné, nýbrž co vyžaduje, aby byly a priori jistým způsobem určeny. Mají-li se totiž vztahovat k předmětu, musí se ve vztahu k němu navzájem nutně shodovat, tj. musí tvořit tu jednotu, která vytváří pojem předmětu. ${ }^{\text {"78 }}$

74 E. Cassirer komentuje Kantovu myšlenku takto: „Nebot' ne proto, že existuje svět věcí, existuje pro nás - jako jeho otisk či obraz - svět poznatků a pravd, nýbrž protože existují nepodmíněně jisté soudy - soudy, jejichž platnost není závislá na jednotlivém empirickém subjektu, který je klade, ani na zvláštních empirických a časových podmínkách, za nichž jsou kladeny -, existuje pro nás řád, který je třeba označit nejen jako řád impresí a představ, nýbrž jako řád předmětů.“ Cassirer si však nevšímá vztahu vydání A a vydání B Kritiky čistého rozumu. Srv. E. Cassirer, Kants Leben und Lehre, Berlin 1918, str. $158 \mathrm{n}$.

75 I. Kant, Kritika čistého rozumu, A 103, str. 523.

76 Tamt., A 104, str. 523.

77 Tamt., A 105, str. 524

78 Tamt., A 104-105, str. 523 n. Srv. J. G. Fichte, O pojmu vědosloví, Druhý úvod do vědosloví, Pokus o nové podáni vědosloví, přel. J. Karásek, Praha 2008, str. 41. 
Aby nebylo mýlky, říká Kant v následující větě, že „ono x, jež jim [představám - M. S.] odpovídá..., není pro nás ničím“ (tj. není transcendentním předmětem). „Ř́káme pak, že poznáváme předmět, když jsme v rozmanitosti názoru způsobili syntetickou jednotu.“79 Tento ,předmět“ nazývá Kant „něčím vůbec“ ${ }^{80}$ resp. „oním x“"81 nebo také „transcendentálním předmětem“. 82 "Čistý pojem tohoto transcendentálního předmětu, “ dodává Kant, ,,je skutečně ve všech našich poznatcích stále týmž x." $" 83$

V dalším textu uvádí Kant příklad toho, že myslet předmět znamená sjednotit rozmanitost názoru podle pravidel: konstrukci trojúhelníku podle pravidla, jímž sjednocuje jeho myšlené predikáty. Pojem trojúhelníku je jen prríkladem toho, že „předmět““ vzniká na základě pravidla. Na základě toho můžeme nyní lépe pochopit předchozí výklad o „syntetické jednotě zkušenosti“. Ve funkci syntézy zkušenosti se uskutečňuje transcendentální apercepce, která jevy „nejen činí nutně reprodukovatelnými“, nýbrž určuje „tím i předmět jejich názoru, tj. pojem něčeho, v čem nutně souvisejí“ ${ }^{84} \mathrm{O}$ něco dále Kant vysvětluje důrazněji: ,Jevy nejsou věcmi o sobě, nýbrž představami, které mají... svůj předmět. Ten tedy... můžeme... nazvat neempirickým, transcendentálním předmětem x." ${ }^{\text {" } 85}$ Tamtéž vysvětluje, že pojem „transcendentálního předmětu“ není názorný a netýká se „ničeho jiného než oné jednoty, která musí být shledána v rozmanitosti poznatku...".

Kant odlišuje od „transcendentálního předmětu“ „empirické pojmy“ naší zkušenosti, které nabývají „objektivní realitu“"86 (mají předmětný význam) tím, že jsou produktem sjednocování zkušenosti kategoriemi, jež jsou opět objektivací logických funkcí myšlení, jak jsme viděli. Kategorie ,jsou tedy i základními pojmy, jimiž vůbec myslíme k jevům objekty, a mají proto apriorně objektivní platnost“ ${ }^{*}{ }^{87}$

\footnotetext{
79 I. Kant, Kritika čistého rozumu, A 105, str. 524.

80 Tamt., A 104, str. 523.

81 Tamt., A 105, str. 524.

82 Tamt., A 109, str. 525.

83 Tamt., A 109, str. 526.

84 Tamt., A 108, str. 525.

85 Tamt., A 109, str. 525.

86 Tamt., A 109, str. 526.

87 Tamt., A 111, str. 527.
} 
Na základě této teorie předmětu může nyní Kant prohlásit: „Apriorní podmínky možné zkušenosti jsou zároveň podmínkami možnosti předmětů zkušenosti.“"88

Ve výkladu zpředmětňující funkce kategorie kauzality, který následuje, užívá Kant místo slova „předmět" slova „událost“ , ${ }^{89}$ protože jde o procesy. Událost není něco, co by následovalo po nějaké jiné události nahodile, $\mathrm{v}$ tom případě by to vědomí pojímalo jako pouhé následování (Folge), nýbrž co následuje nutně podle zákona kauzality. Odtud Kant přechází k úvaze o údajné podivnosti názoru, že by se př́ŕroda měla řídit subjektivním principem, principem apercepce:

„Uvážíme-li však, že tato příroda není o sobě ničím víc než souhrnem jevů, že tudíž není žádnou věcí o sobě, nýbrž jen určitým množstvím představ mysli, pak se nebudeme divit, že ji spatřujeme pouze v transcendentální apercepci, v oné jednotě, díky níž se jedině může nazývat objektem veškeré možné zkušenosti, tj. přírodou. "“90

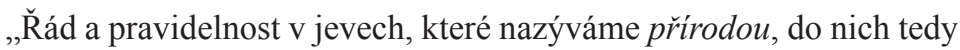
vnášíme sami, a ani bychom je v nich nemohli nalézt, kdybychom je do nich my nebo přirozenost naší mysli původně nevložili.“91

Kant nyní mluví o rozvažování a míní tím kategorie jako objektivizace toho, že subjekt myslí názory:

„Rozvažování... není pouze mohutností vytvářet si pravidla na základě srovnávání jevů; rozvažování je samo zákonodárstvím pro přírodu, tj. bez něj by vi̊bec neexistovala prŕroda, tedy syntetická jednota rozmanitosti jevů podle pravidel. ${ }^{(692}$

A poté se Kant vrací k úvodu své úvahy:

„Jakkoli přehnaně a nesmyslně to snad zní, říkám-li, že rozvažování samo je pramenem př́rodních zákonů, a tedy pramenem formální

\footnotetext{
88 Tamt., A 112, str. 527.

89 Tamt., A 113, str. 527.

90 Tamt., A 114, str. 528.

91 Tamt., A 125, str. 533.

92 Tamt., A 126, str. 534.
} 
jednoty př́rody, je takové tvrzení přece jen správné a přiměřené svému předmětu, totiž zkušenosti. ${ }^{"}{ }^{93}$

Ve druhé analogii zkušenosti se Kant rovněž zabývá výkladem zpředmětnění jevů v empirické předměty. ${ }^{94}$ Při výkladu kategorie kauzality bude sledovat přeměnu vědomí následnosti určitých jevů ve vědomí objektu jako účinku předchozího děje. Aby zdůraznil rozdíl objektivního prožívání následnosti (Folge) od objektivního významu následného děje jako účinku, použivá Kant př́klad aprehenze. Procházím-li v aprehenzi jednotlivé části domu, mohu začít odspoda nebo shora, zleva nebo zprava. Uvědomuji si, že jsem to já, který tyto úkony vykonává. Naproti tomu aprehenze následnosti dvou dějů se mění v objektivní průběh, v průběh reálných věcí, resp. událostí, když přistoupí jistota, že po něčem bude následovat to, co po něm vždy následuje:

nikdy, ani ve zkušenosti, nepřipisujeme následování (nějaké události, když se děje něco, co zde předtím nebylo) objektu - a neodlišujeme tuto následnost od subjektivního postupu naší aprehenze - kromě př́ípadu, kdy má toto následování za základ pravidlo, které nás nutí pozorovat toto pořadí vjemů spíše než nějaké jiné, ba ... je to vlastně toto donucení, které teprve umožňuje představu sukcese v objektu. "95

Je to přechod od následování (Folge) dvou dějů a donucování (Nötigung) mysli k vědomí objektivního průběhu těchto dějů, jímž se dosavadní představy stávají empirickými předměty nebo objektivními událostmi. Kantův rozdíl mezi subjektivním donucením a „sukcesí objektu“ odpovídá Humovu rozdílu mezi determinací mysli, která je ještě subjektivní (je to „nucení mysli““), ${ }^{96}$ a „,nutným spojením předmětư““.97

Za touto změnou je průběh představ pod pravomocí kategorie jako „pravidla“. Charakteristické je použití slovesa „nutí“ a „,nucení“ - tím je vyjadřována ještě subjektivní dimenze prožívání - na rozdíl od „nutnosti“, jíž se vyznačuje objektivní význam událostí chápaných jako (objektivní) „příčina“" a „účinek“.

\footnotetext{
93 Tamt., A 127, str. 535.

94 Tamt., A 233, str. 162.

95 Tamt., A 196, B 242, str. 166 (překlad upraven).

96 D. Hume, Pojednání o lidské přirozenosti, str. 245.

97 Tamt.
} 
Nyní Kant podtrhuje svůj rozdíl od Huma - aprioritu kategorie, která podrobuje smyslové danosti nutnosti. Zdá se sice, ř́íká Kant, že jsme k objektivnímu významu představ přivedeni srovnáváním našeho užívání rozvažování při uvědomování si toho, co je zároveň a co následuje. Rovněž se zdá, že pozorování př́ípadů následnosti nás přivedlo $\mathrm{k}$ tomu, že jsme si vytvořili pojem příčiny. ${ }^{98}$ Ale takový pojem příčiny by byl jen empirický a neměl by bezpodmínečnou platnost, protože by byl založen pouze induktivně.

„S pojmem příčiny se to ale má stejně jako s jinými čistými představami a priori (např. prostorem a časem), které můžeme vyjmout ze zkušenosti jako jasné pojmy jen proto, že jsme je do zkušenosti vložili." “99

Pouze když je následnost dějů založena v neúchylném pravidle podmíněném kategorií, vzniká zkušenost, v níž následnost vnímáme jednoznačně jako určenou objektem - příčinou, která má za následek jiný objekt - účinek. Aby podtrhl apriorní význam pravidla, podle něhož se to, co následuje, stává „účinkem“ (Wirkung), ${ }^{100}$ mluví Kant dokonce o ,zásadě dostatečného důvodu“, podle níž určitá událost vždy nutně následuje po své podmínce. ${ }^{101}$ Jiným způsobem vyjádření je formule o jednoznačném „časovém umístění“:

„Jakmile však vnímám, nebo předjímám, že v této následnosti je vztah k předchozímu stavu, $\mathrm{z}$ něhož představa vyplývá podle pravidla, pak se něco představuje jako událost, nebo jako něco, co se děje, tj. poznávám předmět, který musím dosadit v čase na určité místo, které mu po předchozím stavu nemůže být přiděleno jinak. “102

Jiný výraz, jak vyznačit objektivní význam toho, co mezi našimi představami předchází nebo následuje, je slovo „korelát“, „který se ... vztahuje $\mathrm{k}$ této události, jež je dána, jako $\mathrm{k}$ tomu, co následuje, určujícím způsobem a nutně ji se sebou spojuje v časové řadě“. ${ }^{103}$ „Předmět", „objekt“,

98 I. Kant, Kritika čistého rozumu, A 195, B 241, str. 245.

99 Tamt., A 196, B 241, str. 166.

100 Tamt., A 202, B 247, str. 169.

101 Tamt., A 201, B 246, str. 168.

102 Tamt., A 198, B 243, str. 167 (překlad upraven).

103 Tamt., A 199, B 244, str. 167 (překlad upraven). 
„událost“, resp. „korelát“ toho, co nutně v časové řadě předchází nebo následuje - to jsou výrazy označující objektivní význam představ umist'ovaných do časové řady podle ,pravidla“", tj. (v tomto případě) podle kategorie kauzality. ${ }^{104}$

\section{Kantova kritika racionální psychologie}

Jako autor výkladu já z transcendentální apercepce se Kant musel střetnout s racionální psychologií, jednou ze tří tzv. speciálních metafyzických věd (patří sem ještě racionální kosmologie a racionální theologie). Racionální psychologie vykládala ,já myslím“ jako projev duševní substance. Toto střetnutí s racionální psychologií je předmětem tzv. paralogismů čistého rozumu. I zde musíme uvést, že Kanta v kritice substanciálního pojetí duše předešel Hume. Kantova polemika se substanciálním pojetím duše v racionální psychologii je paralelou k Humově kritice substanciálního pojetí duše, výklad je však sofistikovanější, je zaměřen proti konkrétním teoriím (zatímco Humův výklad vyplývá obecně z jeho skeptické pozice) a hlavně jde o transcendentální teorii. Podle Huma stojí za přesvědčením o osobní identitě, kterou metafyzika vykládá prostřednictvím substance, asociativní sjednocení percepcí. Tak jako vnějším předmětům připisujeme totožnost, třebaže nejsou než jednotlivými percepcemi, ${ }^{105}$ které proběhly v čase, a díky jejich podobnosti, kauzalitě a soumeznosti (contiguity) ${ }^{106}$ je spojujeme a vytváŕíme si iluzi jejich nepřetržitého trvání107 $\mathrm{a}-\mathrm{v}$ dalším kroku - jejich existence oddělené od nás ${ }^{108}$ (a tím je činíme předměty), tak si také $\mathrm{k}$ průběhu percepcí v mysli přinášíme princip, který spojuje jejich jednotlivé př́ipady. Ve skutečnosti je však já pouze „svazek či soubor“109 percepcí, mezi nimiž žádné reálné pouto neexistuje: ${ }^{110}$

„Abychom odstranili přerušování [percepcí - M. S.], předstíráme tímto způsobem trvalou existenci percepcí našich smyslů, a abychom

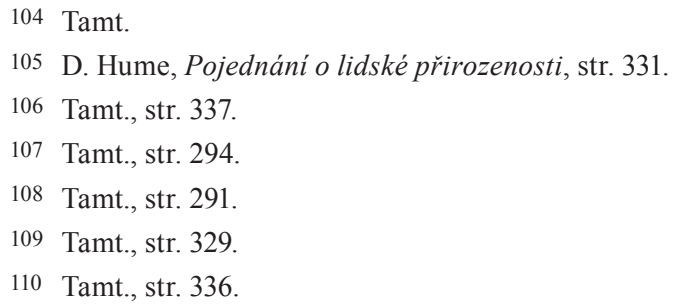


skryli variaci [mezi zdánlivě totožnými percepcemi - M. S.], uchylujeme se k pojmu duše, já a substance. “"111

Hume pokračuje výkladem osobní identity ze sklonu k zaměňování podobných vztahů mezi percepcemi. Vedle zvyku zde působí obrazotvornost, takže si „snadno představujeme cosi neznámého a záhadného“, ${ }^{112}$ co spojuje jednotlivé percepce. Důležité je, že vědomí osobní identity není bezprostřední a přímé (vzniká z reflexe nad průběhem percepcí) a že je pouze fiktivní, podobné identitě připisované rostlinám a živočichům. ${ }^{113}$

Kantova transcendentální teorie odstraňuje fiktivnost já ve prospěch pevné vazby. Kromě toho vykládá já nikoli z objektivního průběhu percepcí, nýbrž z ,já myslím“, ${ }^{114}$ které (jakožto transcendentální apercepce) „Všechny pojmy“ (rozumí se empirické pojmy, předměty zkušenosti) „doprovází.."115

Podle Kanta tkví v poznání toho, co je já, paradoxní obtíž. Záleží v tom, že já jako „transcendentální subjekt“, jako zdroj myšlenek, má být postiženo myšlenkami, které jsou jeho predikáty. ${ }^{116}$ To, co je prvotní, má být poznáno tím, co je druhotné. Je to „nepř́ijemnost", „nepohodlnost“ (Unbequemlichkeit), jíž se nelze zbavit. Ale Kant zároveň naznačuje řešení - já není představa, která by označovala nějaký objekt, nýbrž je to „forma představy vůbec, pokud má být nazvána poznatkem““. ${ }^{117}$ Jde o to, že já nepoznáváme stejným způsobem, jakým funguje naše poznání $\mathrm{v}$ případě předmětů zkušenosti. Modus jeho poznání je zcela jiný. Poznatelné není tak, že bychom se k němu obraceli jako k předmětu, nýbrž tak, že je poznáváme jako akt konstituce všech předmětů, jak víme $\mathrm{z}$ teorie transcendentální apercepce. Naopak jako předmět, a to jako předmět v doslovném, objektivním významu, nikoli jen jako předmět zkušenosti, chce já-duši poznat racionální psychologie. Ta podle Kanta „vydává stálý logický subjekt myšlení za poznání reálného subjektu inherence“."118

Ve vydání A pokračuje Kant podrobným rozborem paralogismů, proto je budeme dále sledovat. Kantovy charakteristiky „nepohodlnosti“ při

\footnotetext{
111 Tamt., str. 331.

112 Tamt.

113 Tamt., str. 330.

114 I. Kant, Kritika čistého rozumu, A 346, B 405, str. 256.

115 Tamt., A 346, B 404, str. 256.

116 Tamt.

117 Tamt.

118 Tamt., A 350, str. 538.
} 
výkladu já si povšiml Hegel v Logice a komentuje ji uštěpačně, vysmívá se tomuto Kantovu slovu. ${ }^{119}$ Ale celá Kantova polemika s racionální psychologií se odehrává jako výklad racionální psychologie a jeho vlastní protipozice, takže úvodní charakteristika „nepř́ijemnosti“ má spíše charakterizovat racionální psychologii.

Podle Kanta já ve funkci logického subjektu neznamená nic věcného, nic reálného. Je to pouhý „transcendentální subjekt", jehož tajemství odhaluje Kantova analýza transcendentální apercepce. Kanta spojuje s racionální psychologií aprioristická pozice: Racionální psychologie chce čistě racionálně, tedy a priori, odvodit základní charakteristiky já, které chápe jako substanci, a proto pojímá tyto charakteristiky jako věcné vlastnosti substance. Podle Kanta jsou to ideální určení nepředmětného já konstituovaného transcendentální apercepcí.

Z toho podle Kanta vyplývá, že o druhém já si mohu učinit představu pouze na základě vlastního sebevědomí, nikoli jako o předmětu, který je vůči mně vnější. Mé vědomí o druhých vzniká přenesením mého vědomí na jiné subjekty. Racionální psychologie chce naopak odhalovat přirozenost myslících bytostí na základě předmětných vlastností (jako je vlastnost jednoduchosti), které nelze apodikticky přičíst myslícím bytostem. ${ }^{120}$

Vedle toho, že racionální psychologie pojímá já věcně, dopouští se ve svých důkazech chyby, kterou logikové nazývají figura dictionis, sofisma ve způsobu řeči. Záleží v tom, že ve vyšší premise se užíá téže kategorie $\mathrm{v}$ obecném významu a $\mathrm{v}$ nižšś premise a závěru $\mathrm{v}$ konkrétnějším významu. Pojem substance ve vyšší premise je „intelektuálním pojmem“, který má smysl bez podmínky smyslového názoru (vše, co doopravdy je, je substancí), zatímco v nižší premise je použit „empiricky vzhledem $\mathrm{k}$ duši, která byla pod tuto podmínku [že je substancí - M. S.] subsumována“. ${ }^{121}$

Racionální psychologie považuje ,já myslím“, na němž je fakticky založena její „,moudrost“, za „vjem existence“, ${ }^{122}$ za „,vědomí sebe sama jako existujícího“. ${ }^{123}$ Ale podle Kanta je to chybný předpoklad, žádný takový původní vjem (Wahrnehmung) vlastní existence (kartesiánské

119 G. W. F. Hegel, Wissenschaft der Logik, vyd. G. Lasson, II, Hamburg 1968, str. 414.

120 I. Kant, Kritika čistého rozumu, A 347, B 405, str. 256.

121 Tamt., A 402, str. 565.

122 Tamt., A 347, B 405, str. 256.

123 Tamt., A 348, B 406, str. 257. 
cogito, ergo sum) neexistuje. Vědomí sebe není původní vjem, je to, jak víme, jistota, že já (já myslím) ,,musí moci doprovázet všechny mé představy“. ${ }^{124} \mathrm{Z}$ tohoto chybného východiska postupuje racionální psychologie k tvrzení, že já je trvalý názor, v němž se stř́idají myšlenky. To je duše jako substance racionální psychologie. Ve skutečnosti žádný takový názor já neexistuje, i když já (,já myslím“) je obsaženo ve všech myšlenkách jako možnost uvědomit si sebe sama. ${ }^{125}$ Trvalost já, kterou racionální psychologie vysvětluje substancialitou duše (ze substanciality duše vyplývá, že ,ani nevznikám, ani nezanikám přirozeným způsobem“), ${ }^{126}$ vyplývá ve skutečnosti z neustálých syntéz našeho vědomí, k nimž je provokováno smyslovými názory. Proto je další charakteristikou, k níž Kant ve své analýze sebevědomí dospívá, že „nikoli vědomí určujícího, nýbrž jen vědomí určitelného já... (dá-li se rozmanitost spojit podle... jednoty apercepce v mysli), je objektem“"127 našeho zkoumání.

Ale Kant nezanedbává ani to, že já musí zároveň určovat, tj. syntetizovat své smyslové názory. To se zdá být dokonce intencí našeho já při syntéze názorů, jak o tom svědčí pojmenování já jako „hybatele“ (Vehikel). ${ }^{128}$

Kant poté přechází k druhému paralogismu, paralogismu jednoduchosti duše. Je to důkaz vztahující se k ,absolutní jednotě subjektu“129 jako podmínce „možnosti každé myšlenky“. ${ }^{130}$ Důkaz jednoduchosti duše jako podkladu její trvalosti sahá k Platónovu Faidónu. Je zajímavé, že Platónem je inspirována i Kantova námitka proti důkazu trvalosti duše z Mendelssohnova spisu Phädon ve vydání B: podle Kebéta může duše v řadě svých fází metempsychózy posléze vyhasnout. ${ }^{131}$ Podle Kanta Mendelssohn opomenul, že duše může být pozměněna ne sice dělením (to je vyloučeno její jednoduchostí), ale postupným ubýváním sil, opomenul tedy hledisko duše nejen jako extenzivní, ale i intenzivní veličiny. ${ }^{132}$

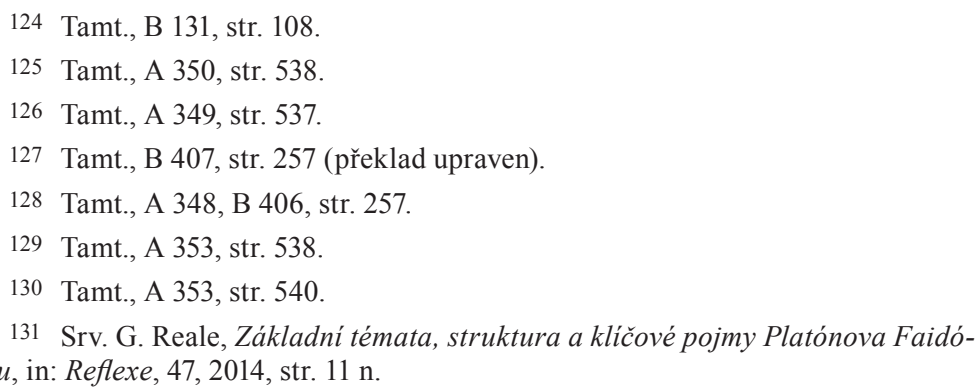

132 I. Kant, Kritika čistého rozumu, B 415, str. 261. 
Kant se k tomuto argumentu vrací v úvaze o rozdílu abstraktního pojmu jednoduchosti a jednoduchosti reálné. Jakkoli věrohodně zní důkaz jednoduchosti naší myslící substance, přece je na místě zásadní pochybnost. $\mathrm{V}$ abstrakci odděluji pohybovou sílu svého těla od jeho jiných vlastností, ale z toho nevyplývá, že mé tělo je jen tato síla. Podobně v abstrakci činíme myšlení jednoduchou představou a na základě toho předpokládáme věc, v níž má být obsaženo pouze myšlení. ${ }^{133}$ Proto platí: „Trvalost duše jako pouhého předmětu vnitřního smyslu ... zůstává ... nedokazatelná..." ${ }^{134}$

V racionální psychologii byla ze substanciality a trvalosti duše vyvozována její numerická identita čili personalita (totožnost duše „V celém čase, jehož jsme si vědomi““). ${ }^{135}$ Kant proti tomu staví identitu nás samých jako „průběžné spojení prostřednictvím apercepce“. ${ }^{136}$ „Identitu osoby lze tedy nevyhnutelně nalézt v mém vlastním vědomí، “137 Dodává k tomu: „,... potud je tento pojem [osobní identity sebe sama-M. S.] nutný a dostatečný také pro praktické používání. “"138 To ukazuje, že Kant od začátku koncipuje svou „logickou identitu“ já s ohledem na praktickou filosofii, kde nabude svůj pravý význam. Místo substanciálního pojetí duše já jako transcendentální apercepce otevřená morálnímu jednání.

Z formulací typu: „Přesto můžeme nechat větu Duše je substance docela dobře platit" ${ }^{\text {139 }}$ nebo „Stejně jako lze podržet pojem substance a jednoduchého, lze podržet i pojem personality, pokud je pouze transcendentální“, ${ }^{140}$ nelze vyvozovat, že Kant má blízko k racionální psychologii, jak soudí Karl Ameriks ve svém komentáŕi k paralogismům ve vydání A. Shovívavost k racionální psychologii je slovní: důraz je na tom, že já musí být pojato transcendentálně a že až tehdy, když jsme si vědomi této zásadní změny v pojetí já, můžeme použít - spíše metaforicky - těchto pojmů. Ameriks se však domnívá, že jde o reálnou blízkost, která vyplývá z toho, že pozadím Kantova pojetí je „fyzická monadologie“

\footnotetext{
133 Tamt., A 784, B 812, str. 261.

134 Tamt., B 415, str. 261.

135 Tamt., A 364, str. 545.

136 Tamt., A 366, str. 546.

137 Tamt., A 362, str. 544.

138 Tamt., A 350, str. 538, A 365, str. 546.

139 Tamt., A 350, str. 538.

140 Tamt., A 365, str. 546.
} 
leibnizovsko-wolffovské školy. ${ }^{141}$ Říká-li Ameriks, že je překvapující, že Kant kritizuje materialismus spíše než to, co je chybného na typicky racionalistické tezi o substancialitě a jednoduchosti duše, pak to není důsledek Kantovy přízně projevované vůči racionální psychologii, nýbrž doklad Humova vlivu na Kanta. Vždyt' Kantova polemika s ,,materialismem“ ve smyslu teze vnějšího světa jako by byla vystřižena z Humova Pojednání. ${ }^{142}$ Ostatně Kant sám se na tomto místě hlásí ke „skeptickému idealismu“ " ${ }^{143}$ resp. k „transcendentálnímu idealismu“. ${ }^{144}$

Čtvrtý paralogismus - paralogismus ideality - se týká vztahu duše $\mathrm{k}$ vnějším předmětům. Rozdíl mezi duší a tělem, stejně jako rozdíl mezi duší a vnějším světem, je rozdílem substancí. Jak může jedno působit na druhé, jak mohou vnější věci vyvolat v duši své duševní obrazy a jak může duše působit navenek, je tedy obtížný problém.

Kantovo řešení tohoto problému je inspirováno Humovou kritikou dualismu našich percepcí a vnějších předmětů. Především nelze pochopit, jak by představy mohly být účinky pohybu vnějších těles, které nemohou způsobit nic než změny v prostorových vztazích. Nelze pochopit, jak by naše myšlenky mohly být účinky působení, které se týká vztahů

„místa, pohybu, tvaru či prostorových určení vůbec, a my tudíž zcela ztrácíme vodítko prríčin, pokud jde o účinky, které by se měly ukázat ve vnitřním smyslu jako těmito příčinami vyvolané. Měli bychom však uvážit, že tělesa nejsou předměty o sobě, jež jsou nám přítomny, nýbrž pouhý jev kdovíjakého neznámého předmětu, že pohyb není účinkem této neznámé příčiny, nýbrž pouze jevem jejího vlivu na naše smysly, že tedy oba tyto jevy nejsou něčím mimo nás, nýbrž pouze představami v nás, a tudíž ... že pohyb sám (a tudíž i hmota, která se jeho prostřednictvím činí poznatelnou) je pouhou představou". ${ }^{145}$

141 K. Ameriks, The Paralogisms of the Pure Reason in the First Edition, in: G. Mohr - M. Willaschek (vyd.), I. Kant, Kritik der reinen Vernunft, str. 377.

142 D. Hume, Pojednání o lidské přirozenosti, str. 333.

143 I. Kant, Kritika čistého rozumu, A 377, str. 552.

144 Tamt., A 378, str. 553.

145 Tamt., A 387, str. 557. 
Sumárně:

„Všechny těžkosti, které se týkají spojení myslící přirozenosti s hmotou, pocházejí... bez výjimky pouze $\mathrm{z}$ oné ... dualistické představy, že hmota jako taková není jevem, tj. pouhou představou mysli..."146

To je velmi podobné Humově kritice „dvojí existence“ percepcí, tj. jejich vědomí jako takových a jako předmětů. ${ }^{147}$

Tím je zároveň řečeno, v jakém smyslu je Kantovo řešení antimaterialistické. Kant zdůrazňuje, že budeme-li studovat svou duši po vodítku zkušenosti a nikoli spekulativně jako racionální psychologie, nedospějeme sice k poznání za hranicemi zkušenosti (to bylo ovšem v racionální psychologii falešným ,vychloubáním“), ale přece dojdeme $\mathrm{k}$ užitku srovnatelnému s tím, který sledovala racionální psychologie. Jde totiž o to, aby bylo naše já uchráněno hrozby materialismu. Spočívá-li nebezpečí materialismu v tom, že naše já bude vyloženo z hmoty, pak v Kantově výkladu apercepce je taková myšlenka vyloučena. Není možné, aby bylo zrušeno myšlení, byla-li by odstraněna hmota; naopak, byla-li by odstraněna myslící substance, musel by „odpadnout celý tělesný svět, který není ničím jiným než jevem ve smyslovosti našeho subjektu...“. ${ }^{148} \mathrm{O}$ tom, že Kantovo „vyvrácení materialismu“ spočívá v poukazu na to, že matérie je pouhý jev v našem já, a tedy na Huma, jsme už mluvili.

Při vší podobnosti Kantových a Humových rozborů musíme ovšem zdůraznit, že Kantova polemika se substanciálním pojetím duše je vedena ze stanoviska apriorně založené zkušenosti a apercepce, která zaručuje totožnost a nepřetržitost individuální zkušenosti v čase, zatímco Hume klade proti substanciálnímu pojetí duše asociativní sjednocení percepcí „bez jakékoli dokonalé jednoduchosti či identity“. ${ }^{149}$ Ř́ká-li Kant, že osobní vědomí je možné i po smrti, i když na základě jiného než smyslového názoru, ${ }^{150}$ je to jen logický důsledek jeho teorie. Je myslitelné, aby transcendentální předmět, který je hypotetickou příčinou vnějších jevů, ale „který vůbec neznáme ani o něm nezískáme žádný pojem“, působil

\footnotetext{
146 Tamt., A 391, str. 559.

147 D. Hume, Pojednání o lidské přirozenosti, str. 288.

148 I. Kant, Kritika čistého rozumu, A 383, str. 555.

149 D. Hume, Pojednání o lidské přirozenosti, str. 379.

150 I. Kant, Kritika čistého rozumu, A 394, str, 561.
} 
i „před začátkem tohoto druhu smyslovosti, díky němuž se nám něco jeví v prostoru“, ${ }^{151}$ a ovšem také poté:

„... názor, že duše může po zrušení veškerého společenství s tělesným světem ještě pokračovat $\mathrm{v}$ myšlení, by se pak ohlásil $\mathrm{v}$ této formě: kdyby měl přestat existovat ten druh smyslovosti, jímž se nám transcendentální a nyní zcela neznámé předměty jeví jako hmotný svět, není tím ještě zrušen veškerý jejich názor a je docela dobře možné, že neznámé předměty jsou myslícím subjektem nadále poznávány, i když ovšem již nikoli jako tělesa." ${ }^{152}$

Názor je podmínkou myšlení, ale je možné, že po smrti máme jiný než časoprostorový názor.

Poté, co Kant vyslovil tuto provokativní tezi, brání se proti těm, jimž se bude zdát tato myšlenka jako př́liš extrémní: at' vznáší námitky proti této možnosti kdokoli, „o absolutní a vnitřní př́íčině vnějších a tělesných jevů toho... ví právě tak málo jako já či někdo jiný“":153

„Nemůže se tedy odůvodněně tvářit, že ví, v čem záleží skutečnost vnějších jevů za nynějšího stavu (za života), tudíž ani, že po něm (po smrti) přestane existovat podmínka veškerého vnějšího názoru nebo také myslící subjekt sám.“154

Naproti tomu Hume si nedovede představit, že by člověk mohl po smrti „vnímat něco jednoduchého a trvajícího, co nazývá svým já“. ${ }^{155}$ Kant tím dokazuje, že jeho výklad z apercepce je s to splnit to, co bylo hlavním záměrem substanční teorie.

\section{Regulativní užívání rozumu}

Poté co Kant vyložil, jak vzniká předmětný význam našich představ vnějšího smyslu, přistupuje k úvahám v tom směru, že jejich předmětný

151 Tamt., A 393, str. 560.

152 Tamt., A 394, str. 560-561 (překlad upraven). Srv. K. Ameriks, The Paralogisms of Pure Reason, str. 388.

153 Tamt., A 394, str. 561.

154 Tamt., A 394, str. 561 (překlad upraven).

155 D. Hume, Pojednání o lidské přirozenosti, str. 329. 
význam může být podmíněn rovněž vlivem „nám zcela neznámého [vnějšího - M. S.] předmětu“. ${ }^{156}$ Tyto úvahy nejsou zradou na „transcendentálním idealismu“, jak míní Jacobi, nýbrž vyplývají i z důsledného uplatnění skeptického stanoviska. Je-li skeptickým stanoviskem, že naše představy nemusejí mít vnější zdroj, pak je na místě i skepse vůči této skeptické myšlence: nemůžeme u nich vyloučit vnější podnět. To říká i Hume ${ }^{157}$ a je na tom vidět, že jde jen o provádění důsledného skepticismu. V souhlase s touto skeptickou motivací přechází Kant velmi opatrně ke zkoumání, zda existuje transcendentní základ jevů.

Začíná otázkou prostoru. U otázky, ,jak je v myslícím subjektu ... možný vnějši názor, totiž názor prostoru (jeho vyplnění, tvar a pohyb)“, můžeme pouze poukázat na „... mezeru svého vědění“, kterou „nemůžeme nikdy vyplnit“, nýbrž jen „označit“, a to „tím, že vnější jevy připíšeme transcendentálnímu předmětu...". ${ }^{158}$ Kant vyvozuje nejprve zápornou stránku tohoto stanoviska: „,.. nikoho nenapadne, aby to, co jednou uznal za pouhou představu, považoval za vnější příčinu.“"159 „Transcendentální předmět" (nyní ve smyslu vnějšího zdroje našich představ vnějšího smyslu) je méně než hypotéza, je to jen označení: hic sunt leones. Nicméně podle Kanta tázání po tom, zda vnější jevy nemají svi̊j základ mimo vědomí, je legitimní. Přijmeme-li totiž vnější jevy jen jako fakta vědomí, opomenuli jsme se tázat po jejich „možnosti““. ${ }^{160}$ Tážeme-li se, jak jsou jevy možné, nemůžeme otázku po jejich vnějším podmínění vyloučit. Poté následuje pozitivnější formulace: „překročíme-li však jejich hranici [tj. pojetí vnějších předmětů jako jevů - M. S.], stane se pojem transcendentálního předmětu nutným. “" ${ }^{161}$

V transcendentální dedukci znamenal ovšem „transcendentální předmět“ předmětný smysl empirického pojmu. Kant používá pojem transcendentálního předmětu dvojím způsobem. Novým významem termínu dává Kant najevo, že přechází k pozitivnější interpretaci vztahu poznání $\mathrm{k}$ vnější skutečnosti. V dalším postupu se ukáže, že Kant sám zastává stanovisko „ideji““, ne však jako nejvyšších metafyzických pomyslů, které se vztahují k nadsmyslovým předmětům - duši, celku světa a Bohu - třem centrům celkovosti světa a jeho smyslu -, nýbrž jako

\footnotetext{
156 I. Kant, Kritika čistého rozumu, A 394, str. 561.

157 D. Hume, Pojednání o lidské přirozenosti, str. 155.

158 I. Kant, Kritika čistého rozumu, A 393, str. 560 (překlad upraven).

159 Tamt., A 390, str. 559.

160 Tamt., A 393, str. 560.

161 Tamt.
} 
vodítek „regulativního“ poznání přírody. To se vyznačuje nikoli adekvací, jako tomu bylo v metafyzickém pojetí idejí, nýbrž přibližováním k pravdě prostř̌ednictvím hypotetických rozvrhů př́rody. Formálním kritériem regulativního poznání je jednota, systémovost a impetus k neustálému rozšiřování poznání. Z tohoto hlediska, jímž vrcholí Kritika čistého rozumu, se ukáže její humovské východisko jen jako prooimion cesty našeho poznání ke stanovisku, které jedině je v souhlase s povahou našeho poznání přírody. Tak jako je tomu v novověké vědě, ani Kantovým stanoviskem není skepse k poznání, proti níž svědčí už jeho neustálý progres, ale rezignace na status absolutní pravdy ve prospěch neustálého přibližování se k ní, aniž kdy může být dosažena. Zkušenostně vykazatelnou funkcí idejí je pořádání našich poznatků, které ideje ,zaměřují k jednomu určitému cíli“ ${ }^{162}$ a ideje „slouží k tomu, aby jim byla opatřena kromě nejvyššího rozšíření i ta největší jednota“. ${ }^{163}$ Jednota, systémovost a neustálé rozšiřování poznatků jsou důsledkem „imanentního“164 užití transcendentálních idejí. Imanentní užití je protichůdné transcendentnímu užití v metafyzice, kdy se ideje vztahovaly k transcendentním nadsmyslovým předmětům. Zároveň však plní - při škrtnutí nadsmyslových předmětů a za podmínky autonomie subjektu - podobný účel: díky idejím ,„poznání nezůstává pouze nahodilým agregátem, nýbrž stává se systémem vzájemně propojeným podle nutných zákonư““. 165

Ideje jsou pojmy nepodmíněných základů tří oblastí skutečnosti. Mají pořádající význam, nebot' jsou to zároveň pojmy absolutních syntéz svých oblastí. ${ }^{166}$ Metafyzika podle Kanta hypostazovala ideje v transcendentní předměty, ${ }^{167}$ a to navzdory tomu, že sestup $\mathrm{k}$ nepodmíněnému je podmíněn transcendentálně - „nebot' podmíněné se sice ... vztahuje k nějaké podmínce, ale nikoli k nepodmíněnému““. ${ }^{168}$ Proto se nepodmíněné „nevyskytuje ve zkušenosti, nýbrž jen v ideji““. ${ }^{169}$ Metafyzika tedy nerespektuje transcendentální založení idejí. Je-li nepodmíněné

\footnotetext{
162 Tamt., A 644, str. 395.

163 Tamt.

164 Tamt., A 643, str. 394.

165 Tamt., A 645, B 673, str. 396.

166 Tamt., A 327, B 383, str. 245.

167 Tamt., A 580, B 608, str. 362.

168 Tamt., A 308, B 364, str. 236. Srv. M. Sobotka, Kant a metafyzika, in: V. Leško - Z. Plašienková (vyd.), Kant v kontextoch Husserlovej a Heideggerovej filozofie, Košice 2009, str. 19.
}

169 I. Kant, Kritika čistého rozumu, A 409, B 436, str. 271. 
produktem transcendentálního podmínění, pak se rýsuje jiné řešení, totiž teorie regulativní funkce idejí.

Teorie regulativního používání idejí je uvedena tímto výrokem:

„Tvrdím tedy, že transcendentální ideje nikdy nemají takové konstitutivní použití [tj. nemohou utvořit pojem předmětu - M. S.], aby jejich prostřednictvím byly dány pojmy určitých předmětů, a v případě, že jim tak rozumíme, jsou to pouze rozumářské (dialektické) pojmy. Na druhé straně ale mají výborné a nepostradatelné regulativní použití, totiž zaměřují rozvažování [rozvažovací poznání - M. S.] $\mathrm{k}$ jednomu určitému cíli, $\mathrm{k}$ němuž se sbíhají paprsky směru všech jeho pravidel do jednoho bodu, který - ačkoli je to pouze idea (focus imaginarius) ..., přesto slouží $\mathrm{k}$ tomu, aby jim opatřil kromě největšího rozšíření i tu největší jednotu." ${ }^{170}$

Kant zdůrazňuje, že poznání vedené idejemi, které nazývá rozumovými pojmy, protože jsou pilíri celkovosti poznání, není s to vytvořit žádné zkušenostní pojmy. Ty mohou být vytvářeny pouze rozvažováním na základě látky, kterou poskytuje smyslovost. ${ }^{171}$ Vztah rozumu - idejí a rozvažovacích zkušenostních pojmů je vztahem „účelného navedení“ (zweckmäßige Anstellung, v českém překladu přeloženo chybně jako „účelné přizpůsobení předmětu“") ${ }^{172}$ empirických pojmů k cíli, jímž je jednota, systematičnost a celistvost poznání.

Kant se důsledně snaží o paralelu mezi starou filosofií a novou transcendentální filosofií. Charakteristickým rysem staré filosofie bylo „povzneseni““ (Aufschwingen) k vyššímu poznání, než jaké dává zkušenost. Toto poznání vzestupuje od „popisného zkoumání popisné stránky světového řádu $\mathrm{k}$ jeho architektonickému spojení z hlediska účelů, tj. podle idejí“. ${ }^{173}$ Metafyzicky odůvodněný vzlet ducha k celistvému pochopení světa, které musí překročit zkušenost, přirovnává Kant k pokroku od pouhého „slabikováni“" knihy světa k jejímu souvislému „čtení“. ${ }^{174}$ Vzlet ducha k celistvosti, při níž se musí překročit zkušenost, zůstává v transcendentální filosofii zachován jediným způsobem, který je

\footnotetext{
170 Tamt., A 674, B 692, str. 395.

171 Tamt., A 310, B 367, str. 237.

172 Tamt., A 644, B 672, str. 395.

173 Tamt., A 318, B 375, str. 241.

174 Tamt., A 314, B 391, str. 239.
} 
oprávněný, protože rekurs k nepodmíněnému, tj. idejím, je podmíněn transcendentálně.

Projekt poznání, jehož úběžník není zkušenostní povahy a který metafyzika naplňovala teorií nadsmyslových předmětů, je podle Kanta řešitelný jedině transcendentální teorií. „Spekulativní zájem“"175 se v poznání rrídí svými „maximami“, jež nejsou „objektivními principy“ (tj. nejsou založeny ve zkušenosti, nedají se z př́rody „vyčíst“), nýbrž jsou vodítky poznání k jednotě, systematičnosti a dalšímu rozšiřování poznatků. Nicméně stejně jako v metafyzice je to poznání „sloužící rozumu“ (zu Gunsten der Vernunft) ${ }^{176}$ tj. celistvému poznání, které překračuje zkušenost.

Teorie regulativního poznání je formulována obecně, jako by platila pro poznání všech tří oblastí skutečnosti, ale ve skutečnosti může být využita pouze pro poznání prírody. Já či duše je vysvětlena z transcendentální apercepce a nejde o poznání hypotetické, nýbrž naprosté.

Poznání Boha opět není možné, jak Kant dokládá vyvrácením ontologického, kosmologického a fyzikotheologického důkazu. Všechny tři důkazy podle Kanta porušují zásadu, že myšlenková nutnost neimplikuje nutnost věcnou. Nutnost a nahodilost jsou jen subjektivními principy rozumu. ${ }^{177}$

Provedení tohoto úkolu je střízlivé a Kant se v něm osvědčuje jako metodolog novověké přírodovědy, a to v rozporu se svou pověstí filosofa, který popírá, že bychom věci opravdu poznávali, jako metodolog pozitivního smyslu poznání, jímž aproximativně pronikáme do jejího nitra. Na rozdíl od ní se však domnívá, že její postupy jsou zakotveny v transcendentálních idejích, tedy konceptech celkovosti, které regulativně vedou naše poznání. Pouze vedou, jak víme. Kant si je vědom toho, že novověká filosofie nepracuje s konceptem metafyzicky předzjednané harmonie mezi řádem bytí a řádem myšlení, nýbrž s konceptem autonomie subjektu, která se projevuje tvorbou hypotéz jako prostředku zkoumání a jejich potvrzením nebo vyvrácením experimentem. Podle Kanta provádí novověká věda stejný experiment zkoušky a vyvrácení ve svém neustálém postupu. ${ }^{178}$

Kant vychází ze stanoviska, že to, co spojuje různá odvětví novověké vědy, je jednota metody, jíž se věda řídí. Ta je určena zřetelem k systematické jednotě poznatků, které nemohou být pouhým agregátem, nýbrž strukturovanou jednotou, založenou na vztahu obecnosti,

175 Tamt., A 666, B 694, str. 406.

176 Tamt., A 649, B 677, str. 398.

177 Tamt., A 616, B 644, str. 380. Srv. H. Vaihinger, Die Philosophie des als ob, Berlin 1919, str. 611.

178 Tamt., B XVIII, str. 20. 
zvláštnosti a jedinečnosti, ale pojatých jinak, než tomu bylo ve starověké vědě. Obecno - at' už jako reálná entita nebo jako vlastnosti - není dáno, nýbrž je přijato hypoteticky a nikoli definitivně. $V$ dalším svém vývoji věda ověřuje, zda následky, které mají z něho vyplývat, skutečně z něho vyplývají, a příp. zpřesňuje, nebo dokonce zavrhne hypoteticky přijaté obecno a navrhne nové. Hypoteticky přijaté obecno je „,pouhá idea“ (tj. není to entita, která by byla dána), u níž se zkouší, zda z ní vyplývají zvláštní príípady, které jsou jisté - a potom se usuzuje na obecnou platnost pravidla pro př́pady, které dány nejsou. ${ }^{179}$ Proto patří k pojmu regulativnosti poznání postup $\mathrm{k}$ dalším poznatkům.

Hypotetické stanovení obecna, jemuž Kant říká „pravidlo“ nebo „zásada“ (Grundsatz), je podkladem sjednocení všech poznatků v „systematickou jednotu“. „Prubířským kamenem“ pravdivosti pravidla je, zda je tento úkol schopno splnit. Poté Kant opětovně zdůrazňuje, že i když pravidlo vyhovuje tomuto kritériu, neznamená to, že by bylo definitivně prijiato. Pravidlo je

„pouze projektovanou jednotou, na niž se nemáme dívat jako na danou o sobě, nýbrž pouze jako na problém. Tato jednota slouží k tomu, abychom našli pro rozmanité a zvláštní používání rozvažování princip a jím toto užívání vedli i v př́ípadech, které nejsou dány, a činili je tak souvislým“. ${ }^{180}$

Ideje, jimiž „pomáháme rozvažovacímu poznání“ $\mathrm{k}$ tomu, aby bylo maximálně rozšířeno, jsou hypoteticky navrhované projekty obecnosti, jak systematicky sjednotit rozvažovací poznatky.

Pro Kanta je vůdčí ideou systematického poznání vztah homogennosti, specifikace a afinity. Není tomu tak, že by tyto rozumové pojmy byly z prrírody čerpány ${ }^{181}$ nýbrž spíše se ,dotazujeme“ " př́rody podle těchto idejí (projektů) ,a považujeme své poznání za nedostatečné tak dlouho, dokud jim prríroda neodpovídá “. ${ }^{182}$ Poté dává Kant př́klad: sotva existuje čistá země, čistý vzduch:

„Přesto potřebujeme jejich pojmy (tedy ty, které mají - co se úplné čistoty týče - svůj původ jen v rozumu), abychom náležitě určili podíl, který má každá $\mathrm{z}$ těchto prírodních příčin na jevu, a tak převádíme

179 Tamt., A 647, B 675, str. 396.

180 Tamt., A 647, B 675, str. 397 (překlad upraven).

181 Tamt., A 645, B 673, str. 396.

182 Tamt., A 646, B 674, str. 396. 
všechny látky na zeminy (takříkajíc na pouhou tíži), na soli a hořlaviny (jako na sílu), a konečně na vodu a vzduch jako na hybatele (jako by na stroje, pomocí nichž ty předchozí působí), abychom vzájemné chemické účinky oněch látek vysvětlili podle ideje mechanismu. "183

Vzhledem k tomu, že jde o poznání překračující zkušenost, nazývá Kant toto poznání rozumovým.

Je potřebou nebo zájmem rozumu, aby vytvořil z poznatků systematickou jednotu, aby nezůstaly pouhým agregátem. Rozum základní formu systému nečerpá (nevyčte) ze zkušenosti, nýbrž stanoví ji hypoteticky a $\mathrm{v}$ dalším zkoumání ji koriguje. Je dáno zvláštní a hledáme obecné ke zvláštnímu jako důsledku obecného. Takovým způsobem hypostazujeme rody prŕrody (nikoli pouze biologické, nýbrž i rody-obecniny ve smyslu uvedeném v př́kladech). Tak se realizuje zájem rozumu na poznání.

V dalším Kant postupuje od pravidel či zásad systému k principu systému, tj. k ideji celku poznatků. Zároveň Kant zdůrazňuje metaforou „dotazování př́rody“, že přecházíme od toho, co platí jen „subjektivně a logicky" ${ }^{184} \mathrm{k}$ tomu, co platí objektivně a vyjadřuje povahu věcí samých. „Pomáháme“ rozvažování tam, „kde samo nedospívá k pravidlům“, abychom zjednali různosti jeho pravidel ,soulad pod jedním principem“. ${ }^{185}$

Nyní Kant zdůrazní, že rozum se svými hypotetickými návrhy, jak uvést poznatky v systematickou jednotu, by nemohl uspět, kdyby nebyl veden transcendentálně. Transcendentální vedení znamená, že tuto systematickou jednotu poznatků můžeme v určité míre postulovat ,a priori ${ }^{\text {“6 }}{ }^{186}$ aniž bychom se mýlili.

Kant propracovává myšlenku, že není možný logický rozvrh systému př́rody, který by poznatky sjednocoval pouze kvůli rozumovému zájmu na systematické jednotě, a že naopak je tento rozvrh možný jen tak, že $\mathrm{v}$ tomto rozvrhu se projevuje příroda sama. Regulativní vedení našeho poznání jde prrírodě vstříc, i když se s ní nikdy zcela nesetká.

U druhého př́kladu reduktivního postupu ${ }^{187}$ (pojmu síly) říká Kant: „Na první pohled vykazují projevy jedné a téže substance takovou

\footnotetext{
183 Tamt. (překlad upraven).

184 Tamt., A 648, B 676, str. 397.

185 Tamt.

186 Tamt.

187 Srv. R. P. Horstmann, Der Anhang zur transzendentalen Dialektik, in: G. Mohr - M. Willaschek (vyd.), I. Kant, Kritik der reinen Vernunft, str. 527.
} 
nestejnorodost“", že předpokládáme téměř tolik sil této substance, kolik se projevuje účinků. Kant opět ukazuje, že postup k základní síle ${ }^{188}$ není jen „ekonomickou zásadou rozumu“ (rozumí se zásadou sjednocení poznatků), nýbrž že tento postup, při němž je náš rozum veden transcendentálně, je i „vnitřním zákonem př́rody“. ${ }^{189}$ Třetím příkladem je eliptická dráha planet, která se takto změnila z kruhové dráhy prostřednictvím „nekonečných mezistupňů“ ${ }^{190}$ „Tak dospíváme pod vedením oněch principů $\mathrm{k}$ tvarové jednotě rodů těchto drah, tím ale dále $\mathrm{k}$ jednotné příčině všech zákonů jejich pohybu (totiž ke gravitaci)... “191 Kant opakuje: „S ohledem na něj [na zákon rozumu - M. S.] musíme proto předpokládat systematickou jednotu př́rody jako naprosto objektivně platnou a nutnou.“ ${ }^{192}$ „Přirozenost věcí sama poskytuje látku k rozumové jednotě." "193

Systém našeho poznání př́rody není tedy jen logický a subjektivní, nýbrž je ve shodě s povahou prŕrody. Rozum v něm nevystupuje zcela autonomně, nýbrž je podmíněn transcendentálně. „Podivuhodným způsobem“ je transcendentální základ poznání př́rody ukryt v metodologických poučkách přírodovědy, aniž o tom jejich uživatelé vědí. ${ }^{194}$ Jde o tyto zásady: „Jsoucna by se neměla zmnožovat, pokud k tomu nejsme nuceni““195 - to je zásada homogenity př́rodních jsoucen - a „rozmanitost jsoucen by neměla být umenšována bez uvážení“. 196 Zatímco první zásada se vztahuje k homogenitě jsoucen, vyjadřuje druhá zákon specifikace. Různost species se nesmí potlačovat. „Třetí zákon,“ ríká Kant, „sjednocuje ony dva tím, že i při největší rozmanitosti přece jen předepisuje stejnorodost, a to stupňovitým přechodem od jednoho k druhému, což naznačuje určitý druh př́buznosti různých větví, pokud všechny vyrazily z jednoho kmene." ${ }^{197}$

Kant zdůrazňuje, že při hledání homogennosti, specifikace a afinity jde spíš o „pravidla“, která rozum ukládá rozvažování, aby tímto

188 I. Kant, Kritika čistého rozumu, A 648, B 677, str. 398.

189 Tamt., A 650, B 678, str. 398.

190 Tamt., A 662, B 690, str. 405.

191 Tamt., A 663, B 691, str. 405.

192 Tamt., A 651, B 679, str. 399 (překlad upraven).

193 Tamt., A 652, B 680, str. 399.

194 Tamt., A 651, B 679, str. 399.

195 Tamt., A 652, B 680, str. 399.

196 Tamt., A 656, B 684, str. 401.

197 Tamt., A 660, B 688, str. 403. 
způsobem postupovalo. ${ }^{198}$ Výsledkem je apriorní stanovení horizontu, v němž „nejvyšší pojem“ „,zahrnuje pod sebou veškerou rozmanitost jako rody, druhy a poddruhy“. 199 „Všechny rozmanité rody jsou jen částmi jednoho jediného svrchovaného a obecného rodu. “200 Kant opětovně poukazuje na „školská pravidla“ a opakuje, že těmito pravidly je zachycována samotná prríroda, že nejde o rozvrh oktrojovaný př́rodě zvnějšku. Kant o těchto pravidlech říká, že se „nedoporučují“ jen svou vhodností, nýbrž že vyjadřují povahu př́rody samé. ,... posuzují úspornost základních příčin, rozmanitost účinků a odtud plynoucí př́ibuznost článků přírody samé o sobě jako přiměřené rozumu a odpovídající prírodě. “201

Kant přitom mluví o „rozšiřování“202 našich poznatků, i když ovšem nikoli za hranice zkušenosti. „Rozum předpokládá rozvažovací poznatky, které jsou nejprve aplikovány na zkušenost, a hledá podle idejí jejich jednotu, která jde mnohem dál, než kam může zkušenost dosáhnout.“203 Toto „dál“ znamená, že zkušenost je jimi - ve svých mezích - zdokonalována dalšími poznatky a spojována systematickým uspořádáním. Dále Kant zdůrazňuje, že poznání se může těmito principy řídit ,jen jakoby asymptoticky, tj. jen se jim přibližovat, aniž by se jich kdy dosáhlo“. ${ }^{204}$ Jako „syntetické věty a priori“ mají „objektivní, i když neurčitou platnost““205 a slouží jako heuristické zásady. Zde Kant používá slovo „idea“ pro zákony jednoty, rozmanitosti a afinity v jejich ideální podobě, která se v prírodě nevyskytuje, ale jíž se naše zkoumání blíží. ${ }^{206}$

Empirické užívání rozumu následuje tyto „ideje“ jen asymptoticky“, tj. ř́íi se jimi, aniž kdy úkol poznat přírodu zcela splní. ${ }^{207} \mathrm{~V}$ tom smyslu jde o ideje jako ideální úběžníky poznání př́ŕrody.

Zásady afinity a specifikace, stejně jako zásada kontinuitní hierarchie, jsou spíše maximami (tj. prripouštějí subjektivní preferenci té či

\footnotetext{
198 Tamt., A 657, B 685, str. 402.

199 Tamt., A 659, B 687, str. 403.

200 Tamt.

201 Tamt., A 661, B 689, str. 404.

202 Tamt., A 673, B 701, str. 410.

203 Tamt., A 662, B 690, str. 404.

204 Tamt., A 663, B 691, str. 405.

205 Tamt., A 664, B 692, str. 405.

206 Tamt., A 664, B 692, str. 404.

207 Tamt., A 663, B 691, str. 405.
} 
oné zásady) než principy vědeckého uspořádání ve zcela objektivním významu. Kant poukazuje na to, že se při charakteristice rostlin, zvířat a lidí nebo i minerálů uplatňuje spíše náklonnost vědce $\mathrm{k}$ afinitě nebo specifikaci než „nahlédnutí objektu““ ${ }^{208}$ To je způsobeno tím, že stejnorodost i specifikace rodů a druhů má stupně, které nelze a priori určit. Principem nemůže být udán přesný stupeň afinity nebo specifikace, proto má princip či maxima spíše heuristický význam. Předměty zkušenosti nejsou těmito zásadami čistého rozumu „určovány“, ale tyto zásady alespoň naznačují „postup, pomocí něhož se může stát empirické a určité zkušenostní užití rozvažování samo se sebou úplně souladným, a to tak, že je, nakolik je to možné, uvedeno v soulad s principem průběžné jednoty...". 209

Na konci 1. oddílu „Dodatku k transcendentální dialektice“ ještě Kant upřesňuje, že pro obě strany (pro tu, která sleduje rozmanitost, i pro tu, která sleduje jednotu) ,je předmět skryt prŕliš hluboko, než aby mohly mluvit na základě poznání přirozené povahy objektu“. ${ }^{210}$ Tato výhrada znamená jen tolik, že sjednoceným použitím maxim poznání je pravda oddalována ,tak dlouho, až je nalezen prostředek, jak sporné zájmy sjednotit a rozum v tomto bodě uspokojit“. ${ }^{211}$

Konečně Kant konfrontuje použití zmíněné metody, resp. „maxim“ poznání s ryzím empirismem - zásadu afinity, která sjednocuje zásadu homogenity, a zásadu specifikace, nelze získat pozorováním:

\begin{abstract}
„Naproti tomu metoda, která podle takového principu hledá v prírodě řád, a maxima nahlížet takový rád jako založený $\mathrm{v}$ př́ŕrodě vůbec, i když zůstává neurčeno, kde nebo jak daleko, je ovšem oprávněným a výborným regulativním principem rozumu. Tento princip však sahá př́liš daleko, než aby se mu mohly zkušenost nebo pozorování vyrovnat." 212
\end{abstract}

V 2. kapitole „Dodatku k transcendentální dialektice“, nazvané „O konečném záměru dialektiky lidského rozumu“, přechází Kant k idejím ve vlastním smyslu. Říká, že jsou nám ,uloženy přirozeností našeho

\footnotetext{
208 Tamt., A 667, B 695, str. 407.

209 Tamt., A 666, B 694, str. 406.

210 Tamt., A 667, B 695, str. 407.

211 Tamt., A 668, B 696, str. 407.

212 Tamt., A 668, B 696, str. 408 (překlad upraven).
} 
rozumu“, 213 který nutně směřuje k jednotě, protože jsou to pojmy „nepodmíněné syntetické jednoty všech podmínek vůbec"“. ${ }^{214}$ Charakteristika úběžníků všeho našeho poznání tedy zůstává stejná jako u principů či maxim vědeckého poznání přírody, ale ideje jsou nejzazší, absolutní úběžníky našeho teoretického poznání.

Kant potom přechází $\mathrm{k}$ výkladu schematizace idejí v předmětu theologické, kosmologické a fyzikotheologické ideje - ale to je již zcela jiná problematika.

Ukázali jsme, že Kant - v rozporu s Jacobiho podezřením - nepřechází od stanoviska transcendentálního idealismu, tj. stanoviska předmětu jako pouhého ,jevu“ naší mysli, k teorii transcendentálního předmětu a posléze $\mathrm{k}$ metodologii poznání přírody svévolně, nýbrž velmi konsekventně. Na rozdíl od Huma, který reprezentuje stanovisko filosofie řídící se požadavkem přísné jistoty bez zřetele $\mathrm{k}$ reálné situaci poznání své doby, postoupil Kant k pojetí filosofie jako organa prírodovědného poznání, ovšem respektující novověkou autonomii subjektu a způsob poznání pomocí hypotéz. To je předznamenáno citátem z Baconova Velikého obnoveni věd, kterým Kant uvádí druhé vydání Kritiky čistého rozumu. To ovšem znamená, že Kantův pojem jevu prochází od úvodních partií Kritiky čistého rozumu, kde se Kant zdá shodovat s Humem (jak si povšiml Jacobi), obloukem k protichůdnému pojetí. Kant sám ř́íá, že vyšel z teze, že nemůžeme poznat ,žádný předmět jako věc samu o sobě, nýbrž jen... jako jev“",215 ale uvedená logika jej přivedla ke stanovisku, že ,tytéž předměty musíme být s to ... alespoň myslet jako věci samy o sobě“. ${ }^{216}$ Tím Kant v širším kontextu, než je jednotlivý důkaz, ${ }^{217}$ řeší ,,skandál filosofie“ ${ }^{218}$ podle něhož nelze dokázat existenci věcí mimo nás. Celá Kritika čistého rozumu poskytuje apagogický důkaz teze světa. ${ }^{219}$

213 Tamt., A 669, B 672, str. 408.

214 Tamt., A 334, B 391, str. 248.

215 Tamt., B XXVI, str. 23.

216 Tamt., B XXVI, str. 24.

217 Ten Kant podává na dvou místech - v B XL (str. 29-30) a ve „Vyvrácení idealismu“ (B 275, str. 183). Důkaz záleží v určitelnosti našeho já něčím trvalým, co přistupuje zvnějšku.

218 I. Kant, Kritika čistého rozumu, B XL, str. 29.

219 Ve shodě s touto tendencí článku odkazujeme průběžně na vydání $\mathrm{A}$, resp. A i B tam, kde se shodují; na vydání B odkazujeme jen ve výjimečných prŕípadech, které vyplynuly ze souvislosti. 


\section{ZUSAMMENFASSUNG}

Der Verfasser erörtert die Schrift David Hume über den Glauben, oder Idealismus und Realismus, in der Jacobi die Bedeutung Humes für die Philosophie untersucht. Kant stimmt mit Hume darin überein, dass der Gegenstand der Erkenntnis nicht als Ding an sich, sondern als Erscheinung aufzufassen ist. Der Unterschied des Bewusstseins vom Gegenstand und des Bewusstseins von uns selbst erweist sich als Unterschied des ,äußeren“ und ,inneren“ Sinnes. Der Begriff der Erscheinung macht jedoch in Kants Kritik einen Bogen von der ursprünglichen Auffassung zu einer entgegengesetzten, nach der wir dieselben Gegenstände, deren wir uns als Erscheinungen bewusst sind, auch als Dinge an sich, d.h. als reale, denken müssen. Die Hauptrolle in dieser Entwicklung kommt dem Begriff des „transzendentalen Gegenstandes“ zu.

\section{SUMMARY}

The author deals with the text David Hume on Faith, or Idealism and Realism where Jacobi estimates the signification of Hume for philosophy. Kant agrees with Hume's claim that the object of knowledge is not to be perceived as thing-in-itself, but rather as appearance. The difference between the consciousness of object and the consciousness of ourselves manifests itself as the difference between the "outer" and the "inner" sense. However, the concept of appearance evolves in Kant's Critique from the initial to the opposite conception according to which we have to think the objects, we are conscious of as appearances, also as thingsin-themselves, that is, as real. The key role in this development plays the concept of the "transcendental object". 